\title{
AKTIVITAS ANTIOKSIDAN DAN PENETAPAN KADAR FENOL TOTAL DARI MIKROALGA LAUT Chlorella vulgaris
}

\author{
Dewi Kurnia $^{1 *}$, Erna Rosliana ${ }^{1}$, Dadang Juanda ${ }^{1}$, Zeily Nurochman ${ }^{2}$ \\ ${ }^{1}$ Prodi Sarjana Farmasi Fakultas Farmasi Universitas Bhakti Kencana \\ ${ }^{2}$ KK Biokimia Departemen Kimia, FMIPA Institut Teknologi Bandung \\ "email: dewi.kurnia@bku.ac.id
}

Received 03 March 2020

Accepted 19 May2020

\begin{abstract}
Abstrak
Antioksidan merupakan senyawa yang dapat menangkal radikal bebas, beberapa penelitian membuktikan mikroalga memiliki aktivitas sebagai antioksidan yang mampu menangkal radikal bebas. Penelitian ini bertujuan untuk menguji aktivitas antioksidan dan penetapan kadar fenol total dari mikroalga Chlorella vulgaris. Ekstraksi dilakukan dengan metode maserasi bertingkat menggunakan pelarut n-heksana, etil asetat, dan etanol 96\%. Uji aktivitas antioksidan dengan peredaman DPPH (2,2-diphenyl-1-picrylhldrazyl) dan penetapan kadar fenol total menggunakan pereaksi Folin-Ciolcalteau. Hasil uji aktivitas antioksidan menunjukan bahwa mikroalga Chlorella vulgaris memiliki aktivitas antioksidan dengan nilai $\mathrm{IC}_{50}$ untuk n-heksana, etil asetat, etanol dan vitamin $\mathrm{C}$ sebagai pembanding berturut-turut sebesar 18,896; 11,979; 20,437 dan 7,895 $\mu \mathrm{g} / \mathrm{ml}$. Hasil penetapan kadar fenol total ekstrak n-heksana, etil asetat, dan etanol berturut-turut sebesar 1,$388 ; 1,184 ; 1,184 \mathrm{mg} / \mathrm{GAE}$ (gallic acid equivalence) per $100 \mathrm{mg}$ ekstrak. Ekstrak etil asetat memiliki aktivitas antioksidan yang sangat kuat dengan nilai $\mathrm{IC}_{50} 11,979 \mu \mathrm{g} / \mathrm{ml}$ dan kadar fenol total yang tertinggi pada ekstrak n-heksana sebesar 1,388 mg/GAE (gallic acid equivalence) per $100 \mathrm{mg}$ ekstrak. Hasil penelitian menunjukan bahwa baik ekstrak nheksan; etil asetat dan etanol memiliki aktivitas antioksidan yang sangat kuat namun ekstrak etil asetat dari mikroalga Chlorella vulgaris lebih potensial untuk digunakan sebagai alternatif sumber senyawa antioksidan.
\end{abstract}

Katakunci: antioksidan, Chlorella vulgaris, DPPH, fenol total.

\begin{abstract}
Antioxidants are compounds that can counteract free radicals, several researches have shown that microalgae have antioxidant activities that can counteract free radicals. This research aims to examine the antioxidant activity and determination of total phenolic compound from Chlorella vulgaris microalgae. Extraction was carried out using multilevel maceration method using solvents n-hexane, ethyl acetate, and ethanol $96 \%$. Activity test by reducing DPPH (2,2-diphenyl-1-picrylhldrazyl) method and determination of total phenol levels using Folin ciolcateau reagent. The results of antioxidant activity test showed that Chlorella vulgaris microalgae antioxidant activity with $\mathrm{IC}_{50}$ values for $\mathrm{n}$-hexane, ethyl acetate, ethanol, and vitamin $C$ as successive comparisons ratio of 18,896, 11,979; 20,437; and $7,895 \mu \mathrm{g} / \mathrm{ml}$. The results of the research were total phenol levels of n-hexane, ethyl acetate and ethanol extracts respectively 1,388; 1,184; 1,184 mg/GAE (gallic acid equivalence) per $100 \mathrm{mg}$ extarct. Ethyl acetate has very strong antioxidant acitivity with an $\mathrm{IC}_{50}$ value of $11,979 \mu \mathrm{g} / \mathrm{ml}$ and the highest total phenol levels from $\mathrm{n}$-hexane amounted of $1,388 \mathrm{mg} / \mathrm{GAE}$ (gallic acid equivalence) per $100 \mathrm{mg}$ extract. The results showed that both n-hexane extract; ethyl acetate and ethanol have very strong antioxidant activity but ethyl
\end{abstract}


acetate extract from microalgae Chlorella vulgaris is more potential to be used as an alternative source of antioxidant compounds.

Keywords: antioxidant, Chlorella vulgaris, DPPH, total phenolic compound.

\section{Pendahuluan}

Mikroalga adalah tumbuhan tingkat rendah yang tidak memiliki akar batang dan daun. Mikroalga adalah produsen alami dari ekosistem perairan yang dapat menghasilkan metabolit yang sangat bermanfaat, sehingga keberadaanya sebagai organisme hidup yang berukuran mikroskopis sudah mulai banyak dikaji (Damianus, 2011). Mikroalga termasuk mikroorganisme fotosintetik yang memiliki kemampuan menggunakan sinar matahari dan karbon dioksida untuk reproduksi sel-sel tubuhnya dan menghasilkan biomassa serta menghasilkan sekitar 50\% oksigen yang ada di atmosfer (Abdurrachman et al., 2013). Keragaman mikroalga menjadikannya sebagai sumber yang potensial untuk menghasilkan berbagai produk kimia dengan aplikasi dalam industri nutrisi, kosmetik, farmasi, dan obat-obatan (Wang H et al., 2010).

Ekstrak dari mikroalga laut merupakan sumber protein, vitamin, dan mineral yang kaya. Salah satu contoh mikroalga yaitu Chlorella vulgaris. Ekstrak dari Chlorella vulgaris mengandung berbagai senyawa aktif biologis termasuk faktor pertumbuhan, zat antiinflamasi dan penyembuhan luka, antioksidan, dan senyawa emolien (Kim $\mathrm{S}$ et al, 2008).

Diantara berbagai kelas antioksidan yang terjadi secara alami, senyawa fenolik seperti fenol sederhana, asam fenolik (turunan dari asam benzoat dan asam sinamat), kumarin, flavonoid, dan lainnya, yang telah diketahui (Wang $\mathrm{H}$ et al., 2010). Ekstrak Chlorella vulgaris strain terisolasi asli yang diperoleh dari ekstraksi karbon dioksida superkritik menunjukkan aktivitas antioksidan yang signifikan dan menyajikan hambatan ganda untuk pertumbuhan sel kanker paeru-paru dan kemampuan migrasi, yang merupakan indeks metastasis kanker (Ibrahim, $\mathrm{K}$ et al., 2015). Uji aktivitas antioksidan dari Chlorella vulgaris telah beberapa kali dilakukan, namun belum diketahui kadar total senyawa fenol yang terkandung didalamnya. Senyawa golongan fenol diketahui merupakan golongan senyawa yang memberikan aktivitas antioksidan. Oleh karena itu, pada penelitian ini dilakukan uji aktivitas antioksidan ekstrak mikroalga Chlorella vulgaris pada beberapa jenis pelarut serta penetapan kadar total fenol yang terkadung.

\section{Metode Penelitian \\ Alat dan bahan}

Alat yang digunakan dalam penelitian ini antara lain seperangkat alat gelas laboratorium, botol kaca kapasitas $1 \mathrm{~L}$, set pipa kaca bentuk L, selang plastik, pipet mikro ukuran ukuran $10-100 \mu \mathrm{L}$ dan 100 $1.000 \mu \mathrm{L}$, lampu neon, haemacytometer, mikroskop, timer, neraca analitik, mortar dan stemper, autoklaf, spektrofotometer UV-Vis (Shimadzu 1800), sentrifuga (Beckmann J2-HS) dan freeze dryer.

Mikroalga yang digunakan dalam penelitian ini adalah kultur murni Chlorella vulgaris yang diperoleh dari Laboratorium Biokimia, Program Studi Kimia, Fakultas Matematika dan Ilmu Pengetahuan Alam, Institut Teknologi Bandung. Bahan-bahan yang digunakan antara lain medium Walne, vitamin B kompleks, aquadest, klorin, $\mathrm{Na}_{2} \mathrm{~S}_{2} \mathrm{O}_{3}$, nheksana, etil asetat, etanol, metanol, DPPH, asam galat, Folin ciocalteu, $\mathrm{Na}_{2} \mathrm{CO}_{3}$.

\section{Pengumpulan Biomassa}

Kultivasi mikroalga Chlorella vulgaris dilakukan pada medium Walne dengan volume total kultur $900 \mathrm{~mL}$, inokulum kultur mikroalga $10 \%(\mathrm{v} / \mathrm{v})$ dari volume total kultur, dan medium $0,1 \%(\mathrm{v} / \mathrm{v})$. 
salinitas medium air laut diatur pada konsentrasi $25 \mathrm{ppt}$, aerasi 24 jam, suhu ruang $\left( \pm 25-27^{\circ} \mathrm{C}\right)$, fotoperiode 12:12 (gelap:terang) dengan intensitas cahaya $\pm 10,000$ lux. Kepadatan sel inokulum kultur sebesar 1 x $10^{6} \mathrm{sel} / \mathrm{mL}$, diukur dengan menggunakan haemocytometer di bawah mikroskop.

Pemanenan biomassa basah dilakukan pada hari ke-8 menggunakan sentrifuga. Biomassa mikroalga dari mediumnya menggunakan setrifuga Beckman J2-HS dengan kecepatan $4000 \mathrm{rpm}$ selama 20 menit pada suhu $0^{\circ} \mathrm{C}$ (Kurnia, 2019). Biomassa yang diperoleh dicuci menggunakan aquades untuk menghilangkan garamnya. Selanjutnya biomassa basah dikeringkan menggunakan Freeze dry untuk memperoleh biomassa kering yang akan digunakan pada proses ekstraksi.

\section{Ekstraksi dan Karakterisasi Ekstrak}

Ekstraksi dilakukan dengan cara maserasi bertingkat menggunakan pelarut n-heksana, etil asetat dan etanol. Sebanyak 20 gram biomassa kering ditambahkan 100 $\mathrm{ml}$ n-heksana lalu disonikasi selama 10 menit kemudian diaduk menggunakan orbital shaker selama 24 jam, maserat dipisahkan dari endapan. Proses ekstraksi dilakukan dengan $3 x$ pengulangan. Ekstrak yang terkumpul kemudian diuapkan sehingga diperoleh ekstrak kental (Kurnia, 2019).

Proses yang sama diulangi pada residu untuk pelarut etil asetat dan etanol secara berturut-turut. Ekstrak kental dikarakterisasi menggunakan metode kromatografi lapis tipis (KLT) dengan fasa diam silika gel $\mathrm{F}_{254}$ dan fasa gerak nheksana - etil asetat (7:3 v/v); n-heksana etil asetat $(5: 5 \mathrm{v} / \mathrm{v})$ dan etil asetat - etanol - air (9:0,5:0,5 v/v). Hasil pemisahan pada KLT kemudian disemprot menggunakan berbagai larutan penampak bercak yaitu $\mathrm{H}_{2} \mathrm{SO}_{4}, \mathrm{FeCl}_{3} 1 \%$, pereaksi Dragendorf dan sitroborat.

\section{Uji Aktivitas Antioksidan}

\section{a. Pembuatan larutan DPPH}

Larutan induk DPPH dibuat dengan menimbang sebanyak $5 \mathrm{mg}$ dengan neraca analitik, dilarutkan dalam metanol p.a 50 $\mathrm{ml}$ sebagai larutan induk, kemudian dibuat seri konsentrasi 20, 30, 40, 50, 60, 80 dan $100 \mu \mathrm{g} / \mathrm{ml}$. Larutan digunakan untuk kurva kalibrasi dengan cara pengukuran serapan pada panjang gelombang $515 \mathrm{~nm}$ menggunakan spektrofotometer sinar tampak.

\section{b. Pembuatan larutan ekstrak mikroalga C.vulgaris}

Sebanyak $50 \mathrm{mg}$ dari masing-masing ekstrak kental dilarutkan dalam $50 \mathrm{~mL}$ metanol p.a sebagai larutan induk. Selanjutnya diencerkan sehingga diperoleh larutan seri konsentrasi 5, 10, 15, 30, 25, 30 dan $35 \mu \mathrm{g} / \mathrm{ml}$.

\section{c. Pembuatan larutan vitamin $C$}

Sebanyak $5 \mathrm{mg}$ vitamin $C$ standar (asam askorbat) dilarutkan ke dalam metanol p.a $50 \mathrm{ml}$ kemudian dibuat larutan seri konsentrasi 2, 4, 6, 8, 10, 12 dan $14 \mu \mathrm{g} / \mathrm{ml}$.

\section{d. Uji kualitatif antioksidan}

Uji kualitatif dilakukan dengan menggunakan metode KLT. Ektrak yang telah dipisahkan pada plat KLT menggunakan beberapa fase gerak selanjutnya disemprot menggunakan larutan DPPH 0,2 \% dalam metanol. Bercak yang memiliki aktivitas antioksidan memberikan warna kuning dengan latar belakang ungu.

\section{e. Uji peredaman $D P P H$}

Larutan seri ekstrak mikroalga ditambahkan larutan DPPH $60 \mu \mathrm{g} / \mathrm{ml}$ dengan perbandingan 1:1 (v/v). Hal yang sama dilakukan pula pada larutan vitamin C sebagai standar pembanding. Campuran sampel dan DPPH diinkubasi pada suhu ruang selama 30 menit dalam kondisi gelap. Aktivitas peredaman DPPH dilakukan dengan mengukur serapan campuran menggunakan spektrofotometri 
sinar tampak pada panjang gelombang 515 nm.

Data absorbansinya yang diperoleh dari tiap konsentrasi masing-masing ekstrak dihitung nilai persen (\%) aktivitas antioksidannya (Arindah, 2010).

Uji aktivitas antioksidan

I $\%$ Hambatan $=\frac{(\mathrm{Ao})-(\mathrm{AS})}{(\mathrm{Ao})} \times 100 \%$

Dimana :

$\mathrm{I}=$ Persen penurunan absorban DPPH

Ao $=$ Absorban larutan DPPH

AS = Absorban larutan sampel setelah ditambahkan DPPH

\section{Penetapan Kadar Fenol Total}

Penetapan kadar fenol total dilakukan dengan menggunakan pereaksi Folin Ciocalteu. Sebanyak 0,5 ml ekstrak sampel ditambahkan $5 \mathrm{ml}$ Folin-Ciocalteu (sebelumnya diencerkan dengan aquadest 1:10), inkubasi 5 menit kemudian ditambahkan $4 \mathrm{ml} \mathrm{Na}_{2} \mathrm{CO}_{3} 1 \mathrm{M}$ dan diinkubasi selama 15 menit. Standar yang digunakan adalah asam galat. Ekstrak dan standar diukur pada panjang gelombang $765 \mathrm{~nm}$. Kadar fenol total dihitung dari kurva kalibrasi asam galat. Total fenol dinyatakan sebagai $\mathrm{mg}$ gallic acid equivalence per $100 \mathrm{mg}$ ekstrak (mg GAE/100 mg ekstrak) (Ghasemi et al, 2009).

\section{Hasil dan Pembahasan}

Kultivasi dilakukan untuk mengumpulkan biomassa sebanyakbanyaknya. Kondisi kultivasi yang akan dilakukan yaitu pada suhu ruang $( \pm 25$ $27^{\circ} \mathrm{C}$ ), fotoperiode $12: 12$ (gelap:terang) dengan intensitas cahaya 10,000 lux dan aerasi selama 24 jam. Kondisi pertumbuhan tersebut merupakan kondisi pertumbuhan optimum yang digunakan untuk kultivasi Chlorella vulgaris (Brataningtyas, 2011). Sebelum dikultivasi kultur dilakukan peremajaan agar kultur yang diperoleh masih dalam kondisi yang baik. Waktu panen yang optimum yaitu pada hari ke-8 (Kurnia,
2019). Sel mikroalga Chlorella vulgaris berbentuk bulat, hidup soliter, berwarna hijau karena terdapat pigmen yang dominan yaitu klorofil seperti pada Gambar 1.

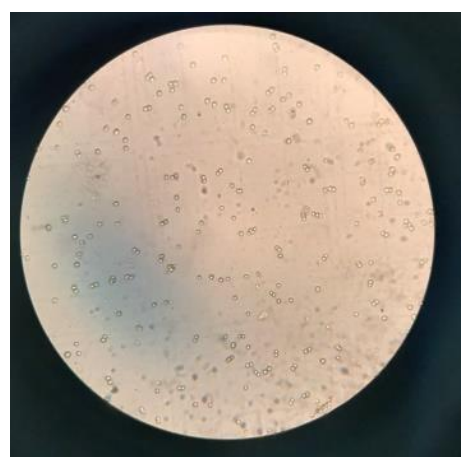

Gambar 1. Mikroalga Chlorella vulgaris dibawah mikroskop

Biomassa basah yang diperoleh dari kultivasi selanjutnya dikeringkan dengan cara Freeze Dry untuk menghilangkan kandungan air dalam mikroalga sehingga diperoleh biomassa kering. Pengeringan juga berfungsi agar adanya air tidak mengganggu proses ekstraksi serta sampel biomassa mikroalga dapat bertahan lama dan tidak ditumbuhi oleh jamur.

Proses ekstraksi dilakukan dengan metode maserasi bertingkat menggunakan pelarut dengan berbagai tingkat kepolaran (n-heksana; etil asetat; etanol). Maserasi merupakan proses ekstraksi cara dingin yang dilakukan dengan cara merendam serbuk simplisia dalam cairan penyari. Cairan penyari akan menembus dinding sel dan masuk rongga sel yang mengandung zat aktif. Zat aktif akan larut dan karena adanya perbedaan konsentrasi antara larutan dan zat aktif di dalam sel dan diluar sel maka larutan didesak keluar (Lukman, 2016). Metode maserasi dipilih karena pada Chlorella vulgaris terdapat senyawa yang mudah teroksidasi dan mudah rusak oleh proses pemanasan. Sedangkan maserasi dilakukan secara bertingkat dengan beberapa pelarut bertujuan agar ekstrak yang diperoleh lebih banyak. Data hasil rendemen ekstrak dapat dilihat pada Tabel 1. 
Tabel 1. Rendemen ekstrak

\begin{tabular}{ccc}
\hline Pelarut & $\begin{array}{c}\text { Bobot } \\
\text { (gram) }\end{array}$ & $\begin{array}{c}\text { \% ekstrak } \\
\text { (b/b) }\end{array}$ \\
\hline N-heksana & 1 & 5 \\
Etil asetat & 2 & 10 \\
Etanol & 2 & 10 \\
\hline
\end{tabular}

Ekstrak mikroalga dengan berbagai pelarut dikarakterisasi dengan metode KLT untuk mengetahui kandungan golongan senyawa pada ekstrak tersebut. Fasa diam yang digunakan adalah silika gel $\mathrm{F}_{254}$ dan fasa gerak n-heksana - etil asetat $(7: 3 \mathrm{v} / \mathrm{v}) ; \mathrm{n}$-heksana - etil asetat $(5: \% \quad \mathrm{v} / \mathrm{v})$ dan etil asetat-etanol-air (9:0,5:0,5 v/v). Penggunaan tiga pengembang dengan tingkat kepolaran yang berbeda bertujuan untuk melihat pola kromatogram senyawa dari ekstrak. Bercak hasil pemisahan dengan KLT disemprot menggunakan beberapa

(a)

(b)

(c)

(d)

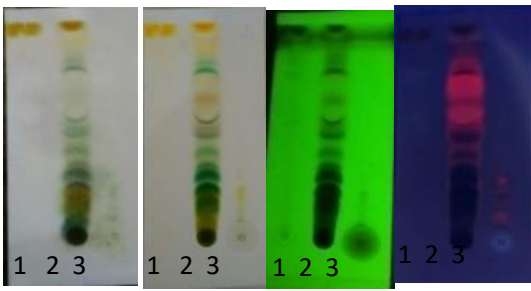

pereaksi penampak bercak. Penyemprotan dengan $\mathrm{H}_{2} \mathrm{SO}_{4}$ pekat digunakan sebagai penampak bercak universal sehingga dapat melihat seluruh komponen senyawa dalam ekstrak. Penyemprotan dengan $\mathrm{FeCl}_{3} 10 \%$ akan menghasilkan warna biru kehitaman untuk menunjukan adanya gugus fenolik. Bercak kehitaman tersebut muncul karena adanya reaksi antara gugus hidroksil pada fenol dengan Fe. Sitroborat digunakan untuk melihat adanya golongan senyawa flavonoid ditunjukkan dengan hasil positif yaitu adanya bercak berwarna kuning kehijauan saat dilihat di bawah sinar lampu UV 365 nm. Penampak bercak Dragendorff digunakan untuk mendeteksi adanya senyawa alkaloid ditandai dengan bercak berwarna coklat kehitaman (Harbone, 1998). Hasil karakterisasi masing-masing ekstrak dapat dilihat pada Gambar 2.

(e)

(f)

(g)

(h)

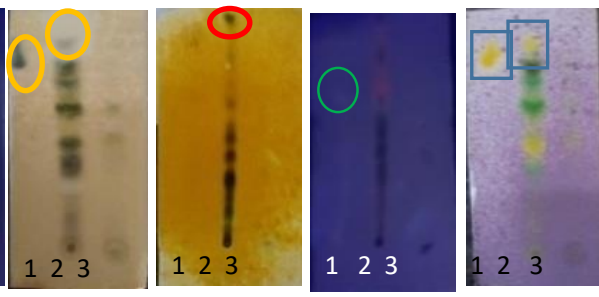

A
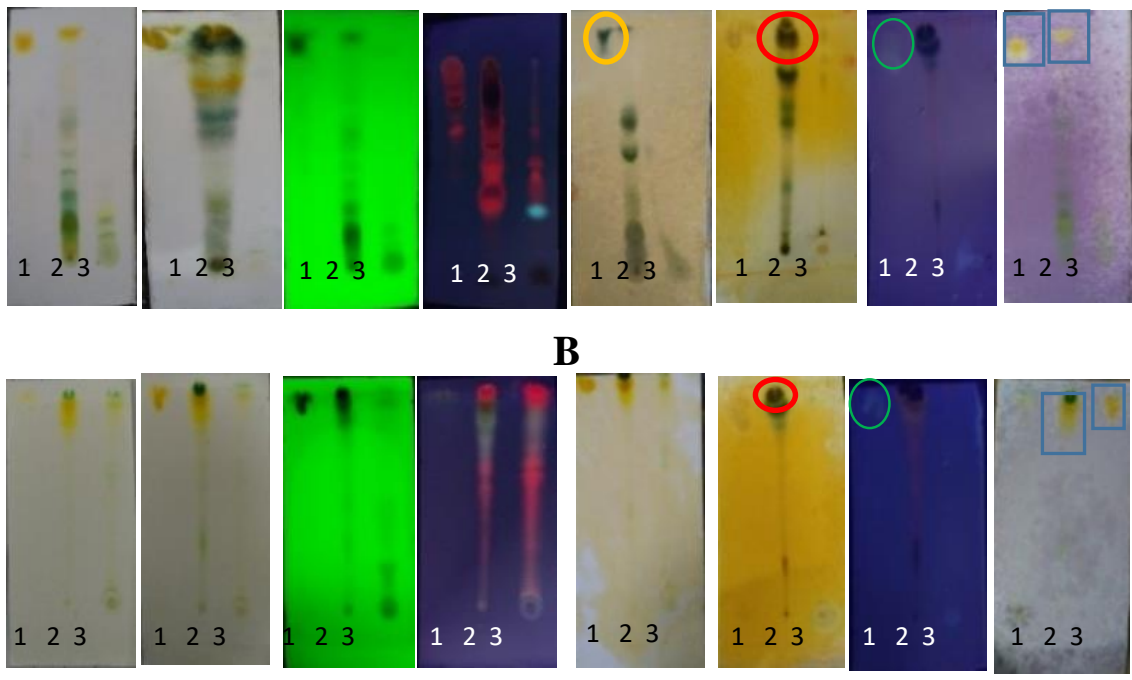

C

Gambar 2. A. Pola Kromatogram menggunakan fase gerak n-heksan - etil asetat (7:3), B. Pola Kromatogram menggunakan fase gerak n-heksan - etil asetat (5:5), C. Pola Kromatogram menggunakan fase gerak etil asetat - etanol - aquadest (9:0,5:0,5). (a) Visual; (b) Penampak bercak $\mathrm{H}_{2} \mathrm{SO}_{4}$; (c) sinar UV $\lambda 254 \mathrm{~nm}$; (d) sinar UV $\lambda 365 \mathrm{~nm}$; (e) Penampak 
bercak $\mathrm{FeCl}_{3}$ 1\%; (f) Penampak bercak Dragendorf; (g) Penampak bercak Sitroborat di bawah sinar UV $\lambda 365 \mathrm{~nm}$; (h) Penampak bercak DPPH 0,2\% dalam metanol.
Keterangan: 1 = fraksi n-heksana
2 = fraksi etil asetat
3 = fraksi etanol
= positif fenol
$\mathrm{O}=$ positif alkaloid
$\bigcirc=$ positif flavonoid
$\square=$ positif Antioksidan

Hasil pemisahan menggunakan plat KLT juga dapat digunakan untuk uji kualitatif aktivitas atioksidan dengan peredaman DPPH. Penampak bercak DPPH $0,2 \%$ dalam metanol digunakan sebagai analisis kualitatif untuk menentukan golongan senyawa yang diduga aktif antioksidan dengan ditandai bercak warna kuning dengan latar belakang warna ungu. Terbentuknya bercak warna kuning disebabkan karena adanya senyawa aktif antioksidan didalam sampel yang dapat mendonorkan atom hidrogen dalam ekstrak sehingga dapat menyebabkan molekul DPPH teroksidasi yang diikuti dengan menghilangnya warna ungu dalam larutan. Hasil uji kualitatif antioksidan dengan KLT menunjukan ketiga ekstrak memiliki respon positif terhadap penyemprotan DPPH 0,2\% yang dapat dilihat pada Gambar 2.

Potensi antioksidan diuji secara kuantitatif dengan menggunakan spektrofotometri sinar tampak terhadap ekstrak menggunakan metode peredaman DPPH sebagai radikal bebas. Metode ini dipilih karena prosedurnya yang cukup mudah, peka, hanya memerlukan sedikit sampel dan tidak memerlukan waktu yang lama. Prinsip dari metode ini adalah adanya donasi atom $\left(\mathrm{H}^{+}\right)$dari substansi yang diujikan kepada radikal DPPH menjadi senyawa non radikal yang akan ditujukan dengan adanya perubahan warna. Penangkapan radikal bebas menyebabkan elektron menjadi berpasangan yang kemudian menyebabkan penghilangan warna yang sebanding dengan jumlah elektron yang diambil (Sunarni et al., 2007).

Sebelum dilakukan pengukuran, sampel yang telah ditambahkan DPPH, diinkubasi terlebih dahulu selama 30 menit. Pada saat inilah terjadi pendonoran proton yang berasal dari ekstrak sampel yang memiliki aktivitas antioksidan sehingga mengakibatkan terjadinya perubahan warna dari yang semula ungu menjadi kuning pucat dan kemudian diukur pada panjang gelombang serapan maksimum DPPH. Semakin pekat perubahan warna kuning yang terjadi semakin kuat pula aktivitas antioksidannya.

Tabel 2. Aktivitas antioksidan ekstrak mikroalga Chlorella vulgaris

\begin{tabular}{ccccc}
\hline \multirow{2}{*}{$\begin{array}{c}\text { Konsentrasi } \\
(\mu \mathrm{g} / \mathrm{ml})\end{array}$} & n-heksana & etil asetat & etanol & Vit C \\
\cline { 2 - 5 } 5 & 39,629 & 44,444 & 44,444 & 33,167 \\
10 & 42,469 & 51,111 & 46,172 & 34,161 \\
15 & 44,938 & 52,716 & 46,419 & 40,124 \\
20 & 50,617 & 53,950 & 50,246 & 50,559 \\
25 & 55,185 & 54,814 & 51,111 & 58,633 \\
30 & 60,740 & 58,271 & 54,074 & 62,732 \\
35 & 62,839 & 59,876 & 56,296 & 73,167 \\
\hline $\mathrm{IC}_{50}$ & 18,896 & $\mathbf{1 1 , 9 7 9}$ & 20,437 & $\mathbf{7 , 8 9 5}$ \\
\hline
\end{tabular}


Berdasarkan hasil uji aktivitas antioksidan sampel ekstrak mikroalga Chlorella vulgaris menggunakan metode DPPH menunjukan bahwa ekstrak Chlorella vulgaris dengan ketiga pelarut yang memiliki kepolaran berbeda yaitu non polar, semi polar, dan polar memiliki aktivitas antioksidan yang sangat kuat.

Penetapan kadar fenol total bertujuan untuk mengetahui jumlah fenol yang terdapat dalam Chlorella vulgaris. Uji kandungan fenol total dianalisis menggunakan reagen Folin Ciolcateu, pereaksi ini merupakan larutan kompleks ion polimerik yang dibentuk dari asam fosfomolibdat dan asam heteropolifosfotungstat yang dapat mengukur semua senyawa fenol dalam sampel uji. Folin ciolcalteu berwarna kuning dan akan berubah menjadi warna biru. Semakin tua intensitas warna biru menandakan semakin tinggi kandungan total fenol dalam ekstrak (Sahidi dan Nazck, 1995).

Fenolat hanya terdapat pada larutan basa, sehingga dilakukan penambahan $\mathrm{Na}_{2} \mathrm{CO}_{3}$ yang bertujuan untuk membentuk suasana basa agar terjadi reaksi reduksi Folin ciolcalteu oleh gugus hidroksil dari fenolik di dalam sampel (Nely, 2007).

Adapun kurva kalibrasi standar asam galat diukur pada panjang gelombang 765 $\mathrm{nm}$ dengan diperoleh nilai $\mathrm{y}=0,0076 \mathrm{x}+$ 0,0649 dan $r^{2}=0,9952$ sesuai dengan Gambar 3.

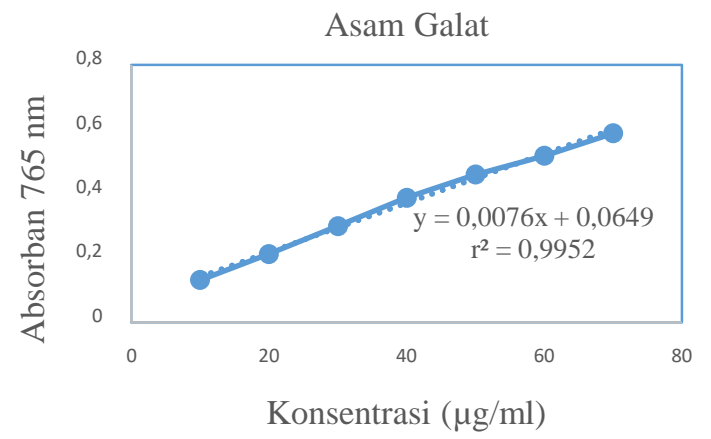

Gambar 3. Kurva kalibrasi standar asam galat pada $\lambda 765 \mathrm{~nm}$.
Tabel 3. Kadar Fenol Total

\begin{tabular}{cc}
\hline $\begin{array}{c}\text { Ekstrak } \\
\text { Chlorella } \\
\text { vulgaris }\end{array}$ & $\begin{array}{c}\text { Kadar Fenol Total } \\
\text { (mg GAE/100 mg } \\
\text { sampel) }\end{array}$ \\
\hline N-heksana & 1,388 \\
Etil asetat & 1,184 \\
Etanol & 1,184 \\
\hline
\end{tabular}

Dari hasil tabel diatas disimpulkan bahwa yang memiliki persentase kadar paling tinggi terdapat pada ekstrak nheksana dengan persentase 1,388 $\mathrm{mg}$ GAE/100 mg ekstrak. Hal ini menunjukan bahwa kandungan fenol yang terdapat pada ekstrak n-heksana paling banyak dibandingkan ekstrak etil asetat dan ekstrak etanol.

\section{Kesimpulan}

Hasil uji aktivitas antioksidan dengan metode peredaman radikal bebas DPPH menunjukan bahwa ekstrak mikroalga Chlorella vulgaris memiliki aktivitas antioksidan dengan nilai $\mathrm{IC}_{50}$ untuk nheksana, etil asetat, etanol dan vitamin $\mathrm{C}$ sebagai standar berturut-turut sebesar 18,896, 11,979, 20,437 dan 7,895 $\mu \mathrm{g} / \mathrm{ml}$. Hasil penetapan kadar fenol total ekstrak n-heksana, etil asetat, dan etanol berturutturut sebesar 1,388, 1,184, 1,184 mg/GAE (gallic acid equivalence) per $100 \mathrm{mg}$ ekstrak. Ekstrak etil asetat memiliki aktivitas antioksidan yang sangat kuat dengan nilai $\mathrm{IC}_{50} 11,979 \mu \mathrm{g} / \mathrm{ml}$ dan kadar fenol total 1,388 mg/GAE (gallic acid equivalence) per $100 \mathrm{mg}$ ekstrak. Hasil penelitian menunjukan bahwa ekstrak etil asetat dari mikroalga Chlorella vulgaris berpotensi sebagai alternatif sumber antioksidan.

\section{Ucapan Terima Kasih}

Ucapan terima kasih penulis ucapkan kepada Lembaga Penelitian dan Pengabdian pada Masyarakat (LPPM) Universitas Bhakti Kencana atas pendanaan penelitian ini melalui Hibah Riset Dasar (Nomor: 001/01.LPPM/UBK/III/2020). 


\section{Daftar Pustaka}

Abdurrachman, O., Mutiara, M., \& Buchori, L., 2013, Pengikatan Karbon Dioksida Dengan Mikroalga (Chlorella vulgaris, Chlamydomonas SP., Spirullina sp.) Dalam Upaya Untuk Meningkatkan Kemurnian Biogas, Jurnal Teknologi Kimia dan Industri, 2(4), 212-216.

Brataningtyas, D. S., 2011, Tesis, Institut Teknologi Bandung, Bandung.

Damianus, M, 2011, Aktivitas Ekstrak Mikroalga sebagai Inhibitor Helikase Virus Japanese Enchephalitis, Skripsi Tidak Diterbitkan, Bogor: Institut Pertanian Bogor.

Ghasemi K, Ghasemi Y, Ebrahimzadeh MA, 2009, Antioxidant activity, phenol and flavonoid contents of 13 citrus species peels and tissues, Pak J Pharm Sci, 22(3), 277-281.

Harborne, J. B., 1998, Phytochemical Methods A Guide to Modern Techniques of Plant Analysis, Springer Science \& Business Media, London, 67.

Ibrahim, K., Ramli, R., Abd Rashid, A. H., \& Mohd Yusof, Y. A., 2015, Antimicrobial property of water and ethanol extract Chlorella vulgaris: A value-added advantage for a new wound dressing material, International Medical Journal, 22(5), 399-401.

Kim S, et al, 2008, Prospective of the Cosmeceuticals Derived from
Marine Organisms, Biotechnol Bioproc Engin, 13, 511-523.

Kurnia, D., Prisdayanti, N., Marliani, L., Idar, I. and Nurochman, Z., 2019, Antiinflammatory Activity from Marine Microalgae Chlorella vulgaris Extract Used Human Red Blood Cells Stability Method (HRBC), Jurnal Kartika Kimia, 2(2), 57-62.

Lukman, A., 2016, Uji Aktivitas Antibakteri Ekstrak Daun Kemangi (Ocimum Sanctum L) Terhadap Bakteri Patogen Dengan Metode KLT Bioautografi, Doctoral Dissertation, Universitas Islam Negeri Alauddin Makassar.

Nely, Fani, 2007, Aktivitas Antioksidan Rempah Pasar dan Bubuk Rempah Pabrik, Skripsi, Institut Pertanian Bogor.

Shahidi, F. dan Nazck, M., 2004, Extraction and Analysis of Phenolics in Food Review, Journal of Chromatography A, 1054, 95-111.

Sunarni, 2007, Flavonoid antioksidan penangkap radikal dari daun kepel (Stelechocarpus burahol (Bl.) Hook f. \& Th.), Majalah Farmasi Indonesia, 18(3), 111-116.

Wang H, et al., 2010, Identification of antilung cancer extract from Chlorella vulgaris C-C by antioxidant property using supercritical carbon dioxide extraction, Proc Biochem, 45, 18651872. 